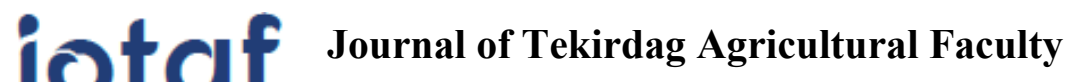

Tekirdağ Ziraat Fakültesi Dergisi
Ocak/January 2022, 19(1)

Başvuru/Received: 29/06/21

Kabul/Accepted: 08/10/21

DOI: $10.33462 /$ jotaf.944704

http://dergipark.gov.tr/jotaf http://jotaf.nku.edu.tr/

ARAŞTIRMA MAKALESI

RESEARCH ARTICLE

\title{
Geotrichum citri-aurantii’nin Sebep Olduğu Turunçgil Ekşi Çürüklük Hastalığının Biyolojik Mücadelesinde Endofit Bakterilerin Biyokontrol Potansiyellerinin Belirlenmesi
}

\author{
Determination of Biocontrol Potentials of Endophytic Bacteria in Biological Control of Citrus \\ Sour Rot Disease Caused by Geotrichum citri-aurantii
}

Soner SOYLU ${ }^{* *}$, Merve KARA², Emine Mine SOYLU ${ }^{3}$, Aysun UYSAL ${ }^{4}$, Şener KURT ${ }^{5}$,

$\ddot{\mathbf{O} z}$

Turunçgil meyveleri, çeşitli fungal hastalık etmenleri tarafindan neden olunan hasat sonrası hastalıklara karşı oldukça duyarlıdır. Geotrichum citri-aurantii'nin neden olduğu ekşi çürüklük, turunçgillerin en önemli hasat sonrası hastalıklarından biridir. Hastalıkla mücadelede genellikle sentetik fungisitler yaygın olarak kullanılsa da söz konusu uygulamaların son yıllarda etkisizliğinin yanı sıra insan sağlığı ve çevre üzerine olan zararlı etkileri birçok çalışmada bildirilmiştir. Hasat sonrası hastalıklara karşı antagonistik bakteri etmenlerinin kullanıldı̆̆ biyolojik mücadele, sentetik fungisitlere umut verici bir alternatif olduğu birçok farklı konukçu bitki patojen ilişkilerinin irdelendiği çalışmalarda araştırılmıştır. Bu çalışmada sağlıklı turunçgil ağaçlarının meyve, dal ve yapraklarından elde edilen endofitik bakteri izolatlarının biyokontrol potansiyelleri G. citri-aurantii'ye karşı petri denemeleri (in vitro) ve meyve testleri (yarı in vivo) ile araştırılmıştır. İzole edilen 24 aday bakteri izolatı arasından seçilen on altı farklı bakteri izolatı G. citri-aurantii'nin misel gelişiminin engellenmesi üzerine olan antagonistik potansiyeli in vitro çalışmalarda değerlendirilmiştir. Test edilen bakteriler arasında Bacillus spp. ait izolatlar fungal etmenin misel gelişimini \% 59.5-78.6 oranında engellemiştir. En yüksek antagonistik etkinlik B. subtilis CM8 (\% 78.6) izolatı tarafindan neden olunmuştur. Acinetobacter johnsonii CT7, Erwinia herbicola CM5, Pseudomonas putida CL2, Pantoea agglomerans CM14, Acinetobacter lwoffii CP1 ve Stenotrophomonas maltophilia CP3 izolatları, ikili kültür denemelerinde misel gelişimini engellemede başarısız olmuştur. Bakteriyel izolatların antagonistik etkinlikleri, fungus inokulasyonundan önceki ön inkübasyon süresi ile artmıştır. Bacillus spp ait izolatlar engellenme bölgesine yakın noktalardaki hiflerde vakuolleşme, büzüşme, şişme ve erime gibi önemli morfolojik değişikliklere neden olmuştur. Yapay olarak enfekte edilen turunçgil meyveleri üzerinde hastalık çıkışı Bacillus spp. ait izolatlar tarafından \% 56.7-83.3 gibi önemli oranlarda baskılanmıştır. Elde edilen sonuçlar, Bacillus spp. ait izolatların güçlü antagonistik aktivitelerinden dolayı, turunçgillerin hasat sonrası hastalık etmen(ler)i ile mücadelesinde biyofungisit olarak kullanılma potansiyeline sahip olduğunu göstermiştir.

Anahtar kelimeler: Turunçgil, Ekşi çürüklük, Geotrichum citri-aurantii, Antagonist, Biyolojik mücadele, Endofit bakteri

\footnotetext{
T*Sorumlu Yazar/Corresponding Author: Soner SOYLU, Hatay Mustafa Kemal Univ., Ziraat Fak., Bitki Koruma Böl., Hatay, Türkiye. E-mail: soylu@mku.edu.tr (iD) OrcID: 0000-0003-1002-8958.

${ }^{2}$ Merve KARA, Hatay Mustafa Kemal Univ., Ziraat Fak., Bitki Koruma Böl., Hatay, Türkiye. E-mail: mervekara@mku.edu.tr (iD) OrcID: 0000-0001-7320-3376. ${ }^{3}$ Emine Mine SOYLU, Hatay Mustafa Kemal Univ., Ziraat Fak., Bitki Koruma Böl., Hatay, Türkiye. E-mail: msoylu@mku.edu.tr 10 OrcID: 0000-0001-59610848 .

${ }^{4}$ Aysun UYSAL, Hatay Mustafa Kemal Univ. Bitki Sağlığı Kliniği Uygulama ve Araştırma Merkezi, Hatay, Türkiye. E-mail: aysun.uysal@mku.edu.tr (10 OrcID: 0000-0002-9067-285X

5Şener KURT, Hatay Mustafa Kemal Univ. Ziraat Fak., Bitki Koruma Böl., Hatay, Türkiye. E-mail: senerk31040@gmail.com (DD OrcID: 0000-0003-4545-5968. Atıf/Citation: Soylu S., Kara M., Soylu E.M., Uysal A., Kurt Ş., Geotrichum citri-aurantii'nin Sebep Olduğu Turunçgil Ekş̧i Çürüklük Hastalığının Biyolojik Mücadelesinde Endofit Bakterilerin Biyokontrol Potansiyellerinin Belirlenmesi. Tekirdağ Ziraat Fakültesi Dergisi, 19 (1), $177-191$.

CBu çalışma Tekirdağ Namık Kemal Üniversitesi tarafından Creative Commons Lisansı (https://creativecommons.org/licenses/by-nc/4.0/)

kapsamında yayınlanmıştır. Tekirdağ 2022 


\begin{abstract}
Citrus fruits are susceptible to postharvest decays caused by various pathogenic fungal disease agents. Citrus sour rot, caused by Geotrichum citri-aurantii is one of the most important postharvest diseases of citrus fruits Although synthetic fungicides are commonly used to combat the disease, ineffectiveness of these applications as well as their harmful effects on human health and the environment have been reported in many studies recently. Biological control of postharvest diseases utilizing antagonistic bacteria has been explored in different host plant-pathogen interactions as a promising alternative to synthetic fungicides. In this study, biocontrol potentials of endophytic bacterial isolates, obtained from fruits, branch and leaves of healthy citrus trees, were investigated against Geotrichum citri-aurantii on petri plates (in vitro) and fruit tests (semi in vivo conditions). Among the 24 putative endophytic bacterial isolates isolated, sixteen different antagonist bacterial isolates were selected and assessed against mycelial growth inhibition of G. citri-aurantii in vitro studies. Among the bacterial isolates tested, Bacillus spp. isolates significantly inhibited mycelial growth of fungal agent by 59.5-78.6\%. The highest mycelial growth inhibition was caused by B. subtilis CM8 (78.6\%). Bacterial isolates of Acinetobacter johnsonii CT7, Erwinia herbicola CM5, Pseudomonas putida CL2, Pantoea agglomerans CM14, Acinetobacter lwoffii CP1 and Stenotrophomonas maltophilia CP3 failed to inhibit mycelial growth in dual culture assays. Antagonistic activities of bacterial isolates increased by the pre-incubation time before fungal inoculation. Bacterial isolates of Bacillus spp. caused considerably morphological changes such as vacuolation, shrivelling, swelling and lysis of hyphae close to inhibition zone. On artificially inoculated fruits, isolates of Bacillus spp. also found to suppressed disease incidence significantly by 56.7-83.3\%. Due to strong antagonistic activities, isolates of Bacillus spp, tested in this study have the potential to be used as biofungicide for controlling post-harvest disease agent(s) of citrus fruits.
\end{abstract}

Key words: Citrus, Sour rot, Geotrichum citri-aurantii, Antagonist, Biological control, Endophytic bacteria 


\section{Giriş}

Ana vatanı Çin, Güneydoğu Asya ve Hindistan olan turunçgillerin, subtropik iklime sahip hemen hemen tüm ülkelerde yetiştiriciliği yapılmaktadır. Ülkemizde en fazla turunçgil yetiştiriciliği subtropik iklime sahip olan Akdeniz ve Ege bölgelerinde yoğunlaşmıştır. Ülkemizde turunçgil meyveleri, üretim miktarı ve dış satım geliri alanlarında yaş meyve ve sebze grubu içerisinde çok önemli bir konuma sahiptir (Anonim, 2020a). TUIK' in 2020 yılı üretim istatistiklerine göre ülkemiz yaklaşı 51 milyon ton yaş meyve ve sebze üretim miktarı ile dünya genelinde önemli üretici ülkeler konumundadır (Anonim, 2020b). Dünya genelinde Turunçgil üretimi, toplam meyve üretimi içerisinde miktar olarak üzüm ve elmadan sonra 2 üçüncü sırada yer almaktadır (Anonymous, 2019). FAO'nun 2019 yılı üretim istatistiklerine göre, Türkiye yaklaşık 4.345.681 ton toplam turunçgil üretimi ile Çin, Brezilya, Hindistan, A.B.D, İspanya, Meksika, Mısır ve İran gibi ülkelerden sonra 9. sırada yer alarak, Dünya turunçgil üretiminin \%3.74'ünü karşılamıştır (Anonymous, 2019).

Turunçgil meyveleri bahçeden sofraya gelinceye kadar farklı aşamalarda birçok fungal hastalık etmeninin saldırısına maruz kalmaktadır. Fungal hastalıklar meyve ve sebzelerde olduğu gibi, turunçgillerin hasadı, depolanması, paketlenmesi ve taşınmaları sırasında en fazla ürün kaybına neden olan biyotik faktörlerin başında gelmektedir (Eckert ve Eaks, 1989). Derim sonrasında turunçgillerde ortaya çıkan hastalıklar arasında mavi ve yeşil küf (Penicillium italicum ve $P$. digitatum) ile ekşi çürüklük (Geotrichum citri-aurantii) ekonomik anlamda en önemli hastalıklar olarak bildirilmişlerdir (Maldonado ve ark., 2009; Bazioli ve ark., 2019).

Turunçgil bahçelerinde yaygın bulunan ekşi çürüklük hastalığı toprak kökenli hastalık etmeni Geotrichum citri-aurantii tarafindan neden olunur. Ascomycotina takımının Saccharomycetes sinıfına ait olan etmenin arthrokonidileri meyve yüzeylerine rüzgar veya yağmur sıçratmasıyla bulaşarak meyvelerde enfeksiyona neden olmaktadır. Ekşi çürüklük sıklıkla yeşil küf ile ilişkilidir ve yeşil küfün varlığı hastalığın gelişimini teşvik eder (Eckert ve Eaks, 1989). Turunçgillerde hasat sonu hastalıklarla mücadelede kullanılan kimyasal uygulamalar hastalık etmeni Geotrichum citri-aurantii’ye karşı yeterince etkili değildir. Nitekim pek çok hasat sonu hastalık etmenleriyle mücadelede kullanılan Imazalil ve Thiabendazole etken maddeleri içeren fungisitler daha sonraki yıllarda Geotrichum citri-aurantii'ye karşı yeterince etkinlik göster(e)mediği veya patojenin kullanılan bu fungisitlere karşı direnç geliştirdiği bildirilmiştir (Liu ve ark., 2009; Horuz ve Kınay, 2010). Hastalık etmenine karşı fungisitlerden sodium o-phenylphenate kısmen etkinlik göstermektedir (Feng ve ark., 2011). Hao ve ark. (2010)'a göre bazı ülkelerde kullanılan ve hastalığa karşı etkili olduğu bildirilen Guazatine terkipli fungisitlerin diğer ülkelerde ruhsatlı olmaması, kullanılan fungistlere karşı patojenin dayanıklı yeni ırklarının gelişmesi, kültürel önlemlerin hastalığın ortaya çıkışında ve epidemi yapmasında etkili olamaması gibi durumlar, üreticiler ve bilim insanlarını hastalık etmeniyle mücadelede yeni alternatif mücadele yöntemlerinin geliştirilmesine yöneltmiştir (Smilanick ve ark., 2007; Smilanick ve Mansour, 2007; Horuz, 2009; Bazioli ve ark., 2019). Son yıllarda hastalık etmenleri ile biyolojik mücadele, dayanıklılığın teşvik edilmesi, doğal bitkisel preparatların kullanılması gibi çalışmalara hız verilmiş ve olumlu sonuçlar alınmaya başlanmıştır (Horuz ve ark., 2019, Bozkurt ve Soylu., 2019). Derim sonrası G. citri-aurantii’nin neden olduğu ekşi çürüklük ile biyolojik mücadele çalışmalarında daha çok mayalar olmak üzere oldukça az sayıda biyolojik mücadele etmeni mikroorganizmaların antagonistik potansiyelleri ve olası biyokontrol mekanizmaları araştırılmıştır (Liu et al., 2010; Hong ve ark., 2014; Kong ve ark., 2016; Soto ve ark., 2018; Bazioli ve ark., 2019; Carmona-Hernandez ve ark., 2019; Bora ve Bora, 2020; Wang ve ark., 2020)

Son yıllarda PGPR veya epifitik bakterilerin yanı sıra endofit bakterilerde biyolojik mücadele kapsamında hastalıklarla mücadelede kullanılmaktadır. Yapılan önceki çalışmalarda, Agrobacterium, Bacillus, Burkholderia, Chryseobacterium, Clavibacter, Curtobacterium, Enterobacter, Micrococcus, Paenibacillus, Phyllobacterium, Pseudomonas, Serratia, ve Stenotrophomonas gibi bakteriyel cinslere dahil birçok endofit antagonistik bakteri türleri farklı kültür ve yabani bitkilerden izole edilerek biyolojik mücadele, bitki gelişimini teşvik etme ile ilişikli çalışmalarda karakterize edilmişlerdir (Sturz ve ark., 2000; Duman ve Soylu, 2019; Aktan ve Soylu, 2020;Soylu ve ark, 2020). Endofit bakteriler yüzey dezenfeksiyonu yapılmış bitki dokularının iç dokularından izole edilen, uygulama yapıldığ Eljounaidi ve ark., 2016; Kara ve ark., 2020). Farklı türlere ait birçok endofit bakteri izolatları genellikle sağlıklı olmak üzere her türlü bitkinin çiçek, yaprak, meyve, gövde, kök ve tohum gibi farklı kısımlarından izole edilmiştir (Tan ve ark., 2012; Duman ve Soylu, 2019; Kara ve ark., 2020). 
Soylu \& Kara \& Soylu \& Uysal \& Kurt Geotrichum citri-aurantii'nin Sebep Olduğu Turunçgil Ekși Çürüklük Hastalığının Biyolojik Mücadelesinde Endofit Bakterilerin Biyokontrol Potansiyellerinin Belirlenmesi

Yapılan literatür araştırmasında turunçgil meyvelerinde ekşi çürüklük hastalık etmeni ile biyolojik mücadele kapsamında daha çok antagonist mayalar ile az sayıda epifit karakterdeki bakterilerin kullanıldığı oldukça kısıtlı sayıda çalışma mevcut olup (Liu ve ark., 2010; Hong ve ark., 2014; Soto ve ark., 2018; Liu ve ark.,2019). Ülkemizde G. citri-aurantii’nin neden olduğu ekşi çürüklük ile biyolojik mücadelede kompostlardan elde edilmiş bakteri izolatlarının kullanıldığı yakın zamanda yapılmış çalışma (Gedik, 2019) dışında, sağlıklı turunçgil ağaçlarından elde edilmiş endofit bakterilerin etkinliğinin araştırıldığı herhangi bir biyolojik mücadele çalışmasına rastlanılmamıştır.

Bu çalışmada turunçgil meyvelerin, dal ve yaprakların iç dokularından elde edilen farklı türlere ait antagonistik potansiyele sahip endofit biyokontrol bakteri izolatlarının izolasyonu, teşhisi, turunçgillerde en önemli hasat sonu fungal hastalık etmenlerinden biri olan G. citri-aurantii'ye karşı biyokontrol etkinliği in vitro ve in vivo koşullarda araştırılmıştır. Ayrıca mikroskobik çalışmalar ile antagonist endofit bakterilerin fungus hifleri üzerindeki etkileri belirlenmiştir.

\section{Materyal ve Metot}

\subsection{Fungal hastalı etmeni Geotrichum citri-aurantii'nin izolasyonu ve tanılanmast}

Fungal hastalık etmeni G. citri-aurantii, sörvey yapılan bahçelerdeki enfekteli mandarin meyvelerinin (Şekil 1A) kabuk dokularından izole edilmiştir. Kesilen parçalar, \%2'lik sodyum hipoklorit ( $\mathrm{NaOCl}$ ) solüsyonunda 2 dakika yüzey sterilizasyonu yapılarak PDA (Potato Dextrose Agar) besi ortamında $25^{\circ} \mathrm{C}$ 'de $5-7$ gün inkübe edilmiştir. PDA besi ortamında gelişen fungal koloniler saflaştırılmış (Şekil 1B) ve fungal kolonilerin tanısı morfolojik ve mikroskobik olarak gerçekleştirilmiştir (McKay ve ark., 2012). Fungus, tek spor izolasyon tekniği kullanılarak saflaştırılmıştır.
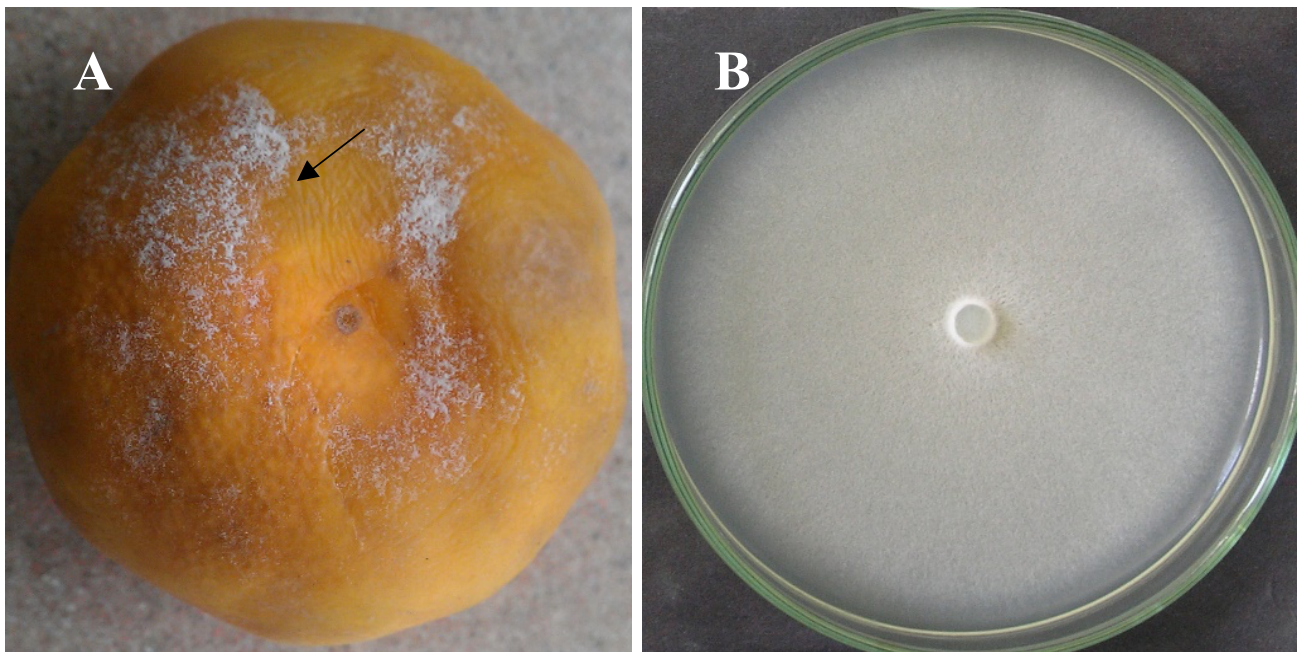

Figure 1. (A) Typical disease symptoms caused by sour rot disease agent $G$. citri-aurantii on mandarin fruits such as softening and sporulation (arrow). (B) Mycelial growth of fungal agent isolated from diseased fruits on PDA nutrient medium

\section{Şekil 1. (A) Ekşi çürüklük hastalık etmeni G. citri-aurantii'nin mandarin meyveleri üzerinde oluşturduğu yumuşama (*) ve sporulasyon (ok) şeklinde görülen tipik hastalık belirtileri. (B) Hastalıklı turunçgil meyvesinden izole edilen fungal etmenin PDA besi ortamındaki misel gelişimi}

\subsection{Endofit bakteri izolatlarının izolasyonu ve seçimi}

Endofit bakteriler yüzey dezenfeksiyonu yapılmış portakal, limon, mandarin ve turunç ağaçlarının meyve, dal ve yapraklarından elde edilmiştir. Sağlıklı bitki örneklerinin yüzeyleri öncelikle \%70'lik etil alkol ile silinmiş, daha sonra \%3'lük çamaşır suyunda 5 dak. bekletilmek suretiyle yüzey dezenfeksiyonları yapılmıştır. Yüzey sterilizasyonu yapılan yaprak, gövde ve meyve örnekleri 3 kez steril su ile durulanmıştır. Yüzey dezenfeksiyonu yapılmış meyvelerin yıkamalarında kullanılan son durulama suyundan alınan $200 \mu \mathrm{l}$ yıkama suyu besi ortamı içeren petriler üzerine yayılmış ve bakteri gelişiminin gözlenmemiş olması dezenfeksiyon işleminin başarısını teyit 
etmiştir (Duman ve Soylu, 2019). Yüzey dezenfeksiyonu yapılan yapraklar doğrudan steril $10 \mathrm{mM} \mathrm{MgCl} 2$ solüsyonunda ( $\mathrm{pH}$ 7.2) ezilmiş ve elde edilen süspansiyon genel [Tryptic Soy Agar (TSA) ve Nutrient Agar (NA)] ve seçici [(King B Agar (KB)] besi ortamlarına (Merck, Germany) ekimleri yapılmıştır. Yüzey dezenfeksiyonu yapılmış gövde ve meyveler ise aseptik olarak üst yüzeyleri kesilip atılmış, alt dokular doğrudan besi ortamların yüzeylerine baskılama (imprinting) yöntemi ile bakteri izolatlarının besi ortamlarının yüzeylerine doğrudan izolasyonları yapılmıştır (Aktan ve Soylu, 2020; Kara ve ark., 2020). Tüm petriler, $26^{\circ} \mathrm{C}^{\prime}$ de 48 saat inkübasyona bırakıldıktan sonra besi ortamların yüzeyinde gelişen farklı morfolojik görünüşteki bakteri kolonilerinden saflaştırmalar yapılmıştır. Petrileri temsilen farklı morfolojik görünüşteki bakteri kolonilerinin her biri "aday antagonist bakteri izolatı" olarak değerlendirilmiştir.

Elde edilen antagonist adayı endofit bakteri izolatları biyolojik etkinlik çalışmalarında kullanılmadan önce bitki hastalık etmeni olup olmadıkları tütün bitkisinde aşırı duyarlılık (HR) testi, patates dilimleri üzerinde yumuşak çürüklük testi ve $37^{\circ} \mathrm{C}$ 'de gelişebilme testlerine tabi tutulmak suretiyle belirlenmişlerdir (Lelliot ve Stead, 1987). Tütünde HR, patates dilimleri üzerinde yumuşak çürüklük oluşturmayan, $37^{\circ} \mathrm{C}$ 'de gelişmeyen izolatlar "aday antagonist endofit bakteri" olarak in vitro ve in vivo biyoetkinlik çalışmalarında kullanılmak üzere teşhisleri yapılıncaya kadar TSA besi yeri içeren petriler üzerinde $+4^{\circ} \mathrm{C}$ 'de saklanmıştır.

\subsection{Endofit bakteri izolatlarinin tanilanmast}

Endofit bakterilerin ön teşhisleri, katalaz ve oksidaz aktivitesi, gram reasiyonu ve KB bes ortamında floresan pigment üretimi gibi biyokimyasal testlerle belirlenmiştir (Lelliot and Stead, 1987). Endofit bakteri izolatlarının tür düzeylerinde tanılamaları MALDI-TOF MS (Matrix Assisted Laser Desorption Ionization-Time of Flight Mass Spectrometer) cihazı (Bruker Daltonics, Bremen, Germany) kullanılmak suretiyle yapılmıştır (Soylu ve ark., 2020). Etanol-formik asit ekstraksiyon yöntemi kullanılarak tek kolonilerden saflaştırılan aday antagonist endofit bakteri izolatlarından protein izolasyonu yapılmış, izolatlara spesifik protein spektrumları Maldi Biotyper Real-Time Classification (RTC) yazılımı (Biotyper 3.0; Microflex LT; Bruker Daltonics GmbH, Bremen, Germany) ile cihazın kütüphanesinde yer alan referans kültür türlerine ait spektrumlarla karşılaştırılmak suretiyle yüksek güvenilirliğe sahip skor değerinde tür düzeylerinde tanılanmışlardır (Chalupová ve ark., 2014).

\subsection{Endofit bakterilerin antagonistik etkilerinin in vitro koşullarda belirlenmesi}

Meyve, dal ve yaprakların iç dokularından elde edilen endofit bakterilerin in vitro biyokontrol (antagonist) etkinlikleri PDA besi yerleri üzerinde ikili kültür testlemeleriyle belirlenmiştir (Soylu ve ark., 2020). Bu testlemelerde besi yerleri üzerinin bir ucuna testlenecek aday endofit bakteri izolatı çizilerek $26^{\circ} \mathrm{C}^{\prime}$ de 2 gün ön inkübasyona bırakılmıştır. Bakteriler geliştikten sonra gelişen koloninin $4 \mathrm{~cm}$ uzağına 5 günlük fungus kültürünün aktif olarak gelişen uç kısmından alınan $5 \mathrm{~mm}$ çapında misel diskler yerleştirilerek ikili kültür kapları $26^{\circ} \mathrm{C}$ 'de gelişmeye bırakılmıştır. Kontrol olarak fungus, bakteri çizimi yapılmamış petrilere aktarılmıştır. Fungusun misel gelişimi kontrol olarak kullanılan petrilerde belirlenen noktaya ulaşmasıyla birlikte, aday endofit antagonist bakteri izolatlarının bulunduğu tüm petrilerde bakteriye doğru gelişen fungus misel gelişimleri $(\mathrm{Mu})$ ölçülmüş ve kontrol petrilerdeki misel $(\mathrm{Mk})$ gelişmesine göre \% engelleme oranları $(\%$ Engelleme $=([\mathrm{Mk}-\mathrm{Mu}] / \mathrm{Mk}) * 100)$ hesaplanmıştır (Soylu ve ark., 2020).

\section{5. Ön inkübasyon süresi ile antagonistik etkinlik arasındaki ilişkinin belirlenmesi}

İkli kültür testleri sonucunda en etkili olduğu belirlenen antagonist izolatlar, PDA besi ortamına fungusların aktarılmasından 1, 24 ve 48 saat öncesinden çizilerek $26^{\circ} \mathrm{C}^{\prime}$ de ön inkübasyona bırakılmış ve ardından fungus kültürü aktarılmıştır. Ön inkübasyon değerlendirmeleri, ikili kültür değerlendirmelerinde olduğu gibi yapılarak misel gelişimlerinin \% engelleme oranları hesaplanmıştır.

\subsection{Endofit bakteri izolatlarının fungus hiflerinin neden oldukları morfolojik değişikliklerin belirlenmesi}

Endofit bakteri izolatlarının bulunduğu petrilerde geliştirilen fungusların miselleri üzerinde meydana gelen morfolojik değişiklikler DIC-Nomarski ekipmanlı 1şık mikroskobu (OLYMPUS BX-51) altında belirlenmiştir. İkili kültür testlerinin yapıldığı petrilerde engellenme bölgesine yakın yerlerdeki hiflerin üzerindeki yapısal değişikliklerin yanısıra petri kaplarının yarısına ulaşan fungus kültürleri üzerine antagonist bakteri süspansiyonları püskürtülerek gelişmeye bırakılmış ve fungus miselleri üzerinde oluşan morfolojik değişikliklerin mikroskobik incelemeleri uygulamalardan 2, 4 ve 7 gün sonra doğrudan besi ortamı üzerinde gelişen miseller üzerinde yapılmıştır. Muamele görmüş fungal yapıları 1şık mikroskobunda incelemek için $\% 50$ glycerol içinde preparatları 
Soylu \& Kara \& Soylu \& Uysal \& Kurt Geotrichum citri-aurantii’nin Sebep Olduğu Turunçgil Ekși Çürüklük Hastalığının Biyolojik Mücadelesinde Endofit Bakterilerin Biyokontrol Potansiyellerinin Belirlenmesi

hazırlanıp, fungal hifler üzerindeki yapısal değişiklikler gözlenmiştir. Ayrıca ikili kültür testlerinde bakteri ile fungus gelişiminin gözlendiği en uç noktada mikroskobik gözlemler yapılarak engellenme bölgelerindeki fungusun hifleri üzerindeki morfolojik değişiklikler kayıt edilmiştir.

\subsection{Endofit bakterileri izolatlarının in vivo koşullarda hastalık gelişimi üzerine biyoetkinliklerinin} belirlenmesi

Fungal süspansiyonun hazırlanması için; G. citri-aurantii izolatı PDA besi ortamında $26^{\circ} \mathrm{C}$ 'de 7 gün boyunca gelişmeye bırakılmıștır. İnokulum süspansiyonu, 5 günlük fungus kültürlerinin bulunduğu besi ortamı üzerine 50 $\mathrm{ml}$ steril su eklendikten sonra steril cam bagetle yüzeyinden sporlar kazınıp, hazırlanan süspansiyonun konsantrasyonu hemositometre yardımıyla $10^{6}$ arthrospor/ml olacak şekilde ayarlanmıştır (Kara ve Soylu, 2020).

Bakteri süspansiyonunun hazırlanması için; in vitro etkinlik çalışmaları sonuçlarına göre seçilen 10 endofit bakteri izolatın in vivo etkinliklerini belirlemek için, seçilmiş bakteri izolatları sıvı besi yerinde (LB) orbital çalkalamalı inkübatörlerde 200 rpm'de 48 saat boyunca geliştirilmiştir. Sıvı kültürde gelişen bakteri hücreleri soğutmalı santrifüj ile çöktürülerek pelet haline getirilmiş, üst kısımdaki sıvı besi ortamı (supernatant) atıldıktan sonra pelet steril $10 \mathrm{mM} \mathrm{MgCl} 2$ solüsyonu ile sulandırılmış, bakteri süspansiyon konsantrasyonları ( $10^{8}$ hücre $\left./ \mathrm{ml}\right)$ spektrofotometre yardımıyla (Perkin Emler, Lambda 25, USA) $620 \mathrm{~nm}$ dalga boyunda ölçülerek çalışmalarda kullanılmıştır.

Antagonist bakterilerin in vivo etkinliği 5 lt kapasiteli cam kavanozlar içinde belirlenmiştir. Sağlıklı turunçgil meyveleri (cv. Owari Satsuma) öncelikle bahçeden dikkatli bir şekilde hasat edildikten sonra yüzey sterilizasyonu yapılmış ve orta ekseni boyunca 4 farklı noktaya kürdanla yara açılıp, daha önceden hazırlanan fungal spor süspansiyonundan $50 \mu \mathrm{l}$ damlatılmışır (Kara ve Soylu, 2020). Uygulama görmüş meyveler laboratuvarda kurumaya bırakıldıktan 1 saat sonra üzerlerine hazırlanan bakteri süspansiyonu püskürtülmüştür. Uygulama yapılan meyveler $(n=5) 5 \mathrm{lt}$ kapasiteli kavanozlarda $(\mathrm{n}=3)$ oda sıcaklığında $\left(22^{\circ} \mathrm{C}\right)$ inkübasyona bırakılmıştır. Kontrol olarak fungusla inokule edilmiş meyveler üzerine bakteri süspansiyonu yerine steril su püskürtülmüştür. Uygulama yapılan meyvelerde hastalık gelişimi yumuşama oluşumu ve çapları ölçülmek suretiyle kontrol meyvelerindeki gelişmeyle kıyaslanarak bakterilerin etkinliği ortaya konulmuştur.

\section{8. İstatistik analizi}

Laboratuvar koşullarında yürütülen in vitro ve in vivo denemeler, tesadüf parselleri deneme desenine göre kurulmuş, her bakteri izolat-fungus kombinasyonu için ölçümler [misel gelişimi ve yumuşak çürüklük çapları $(\mathrm{mm})] 3$ tekrarlı olmak üzere 5 farklı petri/meyve üzerinde yapılmış ve deneme 2 farklı zamanda tekrar edilmiştir. Elde edilen tüm veriler \%etkinliğe çevrilmeden, IBM SPSS istatistik programı (versiyon 17.0) kullanılarak tek yönlü ANOVA ile varyans analizi yapılmış ve Duncan çoklu karşıllaştırma testi ile izolatlar arasındaki farklılıklar tespit edilmiştir.

\section{Araştırma Sonuçları ve Tartışma}

\subsection{Fungal hastalık etmeni Geotrichum citri-aurantii'nin izolasyonu ve tanılanmast}

Fungal kültürün elde edilmesi için, derim sonrası bahçeden depoya veya paketleme tesisine getirilen ve hastalıklı olduğu düşünülen mandarin meyvelerinden izolasyon işlemi yapılmıştır. Hastalıklı dokular PDA besi ortamı içeren petrilerde $25^{\circ} \mathrm{C}^{\prime}$ de 5-7 gün süre ile inkübasyona bırakılmıştır. Gelişen kolonilerden yapılan mikroskobik gözlemler sonucunda besi yerinde beyaz, dairesel olarak ve hızlı gelişen, göreceli olarak seyrek koloniler incelenmiştir. Hif ve konidi yapısı gibi morfolojik ve taksonomik karakterlere dayanarak etmenin Geotrichum citri-aurantii türü olduğu tanımlanmıştır (McKay ve ark., 2012).

\subsection{Endofit bakteri izolatlarının izolasyonu}

Hatay ilinin en fazla turunçgil tarımının yapıldığı Erzin ilçesinin farklı bahçelerindeki sağlıklı limon, mandarin, portakal ve turunç gibi ağaçların meyve, yaprak ve dalların iç dokularından toplam 34 adet endofit karakterde aday antagonist bakteriyel izolat elde edilmiştir. Elde edilen bu izolatlar öncelikle bitki patojeni olup olmadığının belirlenmesi amacı ile tütünde aşırı duyarlılık testine tabi tutulmuştur. Yapılan test sonucunda 34 aday bakteriden 
28 adet bakterinin inokulasyon noktasında herhangi bir duyarll1ık belirtisine neden olmazken, 5 izolat patates dilimleri üzerinde yumuşak çürüklüğe neden olmuş, 7 izolat $37^{\circ} \mathrm{C}$ 'de gelişim göstermiş olup bu izolatların potansiyel bitki ve insan patojeni olma olasılığı nedeniyle denemelerden çıkartılmıştır. Geri kalan 16 antagonist bakteri izolatı ile detaylı çalışmalar yapılmaya karar verilmiştir.

\subsection{Endofit bakteri izolatlarinin tanilanmast}

İzolasyon çalışmaları sonucunda insan ve bitki patojeni olmadığı belirlenen 16 adet endofit antagonist bakteri izolatının turunçgil meyvelerinde ekşi çürüklük olarak bilinen hastalığa neden olan fungal etmen G. citriaurantii'ye karşı antagonistik potansiyelleri in vitro koşullarda araştırılmıştır. Elde edilen 16 izolat yapılan MALDI-TOF MS analizleri sonucundan 5 tanesi Bacillus subtilis (CP4, CM8, CL10, CL12, CL15), 2 tanesi Bacillus amyloliquefaciens (CM9, CM11) diğerleri ise Serratia marcescens, Acinetobacter lwoffii, Stenotrophomonas maltophilia, Pantoea agglomerans, Pseudomonas koreensis, Pseudomonas putida, Erwinia herbicola, Acinetobacter johnsonii, Pseudomonas frederisbergensis olarak belirlenmiştir.

\subsection{Endofit bakterilerin antagonistik etkilerinin in vitro koşullarda belirlenmesi}

Endofit bakterilerle fungal etmenin birlikte yer aldıkları ikili kültür testlerinde, Bacillus spp. ait izolatların fungal etmenin misel gelişimini \%59.5-78.6 gibi oldukça yüksek oranda engellediği belirlenmiştir (Tablo 1). Bakteri izolatları arasında fungus misel gelişiminin engellenmesinde en yüksek antagonistik etki B. subtilis CM8 izolatının bulunduğu ikili kültür petride \%78.6 oranında tespit edilmiştir (Tablo 1 ve Şekil 2). İzolatlar içinde Acinetobacter johnsonii CT7, Erwinia herbicola CM5, Pseudomonas putida CL2, Pantoea agglomerans CM14, Acinetobacter lwoffii CP1 ve Stenotrophomonas maltophilia CP3 misel gelişimini engellemede kontrol ile karşılaştırıldığında etkili olmadığı belirlenmiştir (Tablo 1, Şekil 2). Bacillus türleri dışında bir diğer antagonist tür olan Serratia marcescens CT6 izolatı patojen gelişimini \% 43.5 gibi yüksek oranda engellemiş olup, Bacillus türlerinden istatistiksel olarak farklı bir grupta yer almıştır (Tablo 1).

Tablo 1. Turunçgil meyve, yaprak ve dalların iç dokularından elde edilen antagonist endofit bakteri izolatının in vitro koşullarda fungal hastalk etmeni G. citri-aurantii'nin misel gelişimini engelleme (\%) potansiyeli ${ }^{a}$

Table 1. In vitro inhibitory (\%) potentials of endophytic bacterial isolates, obtained from inner tissues of fruits, leaves and branches, against mycelial growth of fungal disease agent $\mathrm{G}$. citri-aurantii ${ }^{a}$

\begin{tabular}{lcc}
\hline Tür ismi & $\begin{array}{c}\text { Misel gelisisimi } \\
(\mathbf{m m})^{\mathbf{b}}\end{array}$ & $\begin{array}{c}\text { Misel gelişiminin } \\
\text { engelleme oranı (\%) }\end{array}$ \\
\hline G. citri-aurantii CM1 & $43.7^{\mathrm{g}}$ & 0.00 \\
Bacillus subtilis CM8 & $9.3^{\mathrm{a}}$ & 78.6 \\
Bacillus subtilis CP4 & $11.7^{\mathrm{ab}}$ & 73.3 \\
Bacillus amyloliquefaciens CM9 & $12.0^{\mathrm{ab}}$ & 72.5 \\
Bacillus amyloliquefaciens CT11 & $12.7^{\mathrm{ab}}$ & 71.0 \\
Bacillus subtilis CL15 & $13.0^{\mathrm{ab}}$ & 70.2 \\
Bacillus subtilis CL12 & $13.7^{\mathrm{b}}$ & 68.7 \\
Bacillus subtilis CL10 & $17.7 \mathrm{c}$ & 59.5 \\
Serratia marcescens CT6 & $24.7 \mathrm{~d}$ & 43.5 \\
Pseudomonas frederisbergensis CM13 & $28.7^{\mathrm{e}}$ & 34.4 \\
Pseudomonas koreensis CL16 & $36.0^{\mathrm{f}}$ & 17.6 \\
Acinetobacter johnsonii CT7 & $39.7^{\mathrm{g}}$ & 9.2 \\
Erwinia herbicola CM5 & $40.3^{\mathrm{g}}$ & 7.6 \\
Pseudomonas putida CL2 & $40.7^{\mathrm{g}}$ & 6.9 \\
Pantoea agglomerans CM14 & $41.0^{\mathrm{g}}$ & 6.1 \\
Acinetobacter lwoffii CP1 & $41.7^{\mathrm{g}}$ & 4.6 \\
Stenotrophomonas maltophilia CP3 & $43.3^{\mathrm{g}}$ & 0.8 \\
\hline
\end{tabular}

a Bakteri izolatları PDA üzerine patojen inokulasyonundan 48 saat önce çizilmiştir. Bakterilerin bulunduğu petrilerde fungusun bakteriye doğru giden misel gelişimi $(\mathrm{mm})$ ölçülerek kontrol petrilerdeki gelişmeye göre kıyaslanmış ve engelleme oranları (\%) hesaplanmıştır.

b Elde edilen değerler 5 farklı petri kabında ölçümlerin ortalaması olup, deneme farklı zamanlarda 2 kez tekrar edilmiştir. Sütun içerinde yer alan ortalama değerlerin yanındaki farklı harfler izolatlar arasındaki farkın istatistiksel olarak önemli olduğunu göstermektedir (Duncan Çoklu Karşılaştırma Testi, $P<0.05$ ). 
Soylu \& Kara \& Soylu \& Uysal \& Kurt Geotrichum citri-aurantii'nin Sebep Olduğu Turunçgil Ekși Çürüklük Hastalığının Biyolojik Mücadelesinde Endofit Bakterilerin Biyokontrol Potansiyellerinin Belirlenmesi

Mohammadi ve ark., (2017) Bacillus subtilis, B. pumilus, B. cereus, B. megaterium ve Agrobacterium radiobacter türlerine ait epifit bakteri izolatlarının turunçgillerde Penicillium digitatum'a karşı antagonistik özelliklerini in vitro koşullarda araştırdıkları çalışmada en ümitvar bakterilerin $B$. subtilis ve A. radiobacter olduğunu bildirmişlerdir. Benzer şekilde Soto ve ark. (2018) limon meyvelerinde hasat sonrası fungal hastalık etmenlerinden Geotrichum citri-aurantii, Penicillium digitatum, Penicillium italicum ve Phyllosticta citricarpa'ya karşı maya, fungus izolatlarının yanısıra Bacillus amyloliquefaciens, Bacillus subtilis, Paenibacillus polymyxa, Pantoea agglomerans ve Pseudomonas syringae gibi bakteri izolatların fungal etmenlerin misel gelişimini engellemede değişen oranlarda etkinlikler gösterdiğini bildirmişlerdir. Hong ve ark. (2014) mandarin meyvelerinde Penicillium digitatum, P. italicum ve Geotrichum citri-aurantii'nin neden olduğu hastalıkları engellemede sicak su uygulaması ile birlikte epifitik Bacillus amyloliquefaciens HF-01 izolatı ile sodium bicarbonate kombinasyonun etkinliğini araştırdıkları çalışmalarında kontrole kıyasla meyvelerde hastalık çıkışını \%80 oranında azalttığını bildirmişlerdir. Ghazanfar ve ark. (2016) tarafından domates meyvelerinde hasat sonrası meyve çürüklüğüne neden olan bir diğer türü Geotrichum candidum'a karşı sağlıklı domates bitkilerinin kök bölgelerinden 25 farklı fungal ve bakteriyel izolat elde etmişlerdir. Yapılan ikili kültür testlerinde, Trichoderma harzianum, Bacillus spp., ve Pseudomonas fluorescens izolatların fungal etmenin in vitro koşullarda misel gelişimini, in vivo koşullarda ise hastalık çıkışını etkili bir şekilde engellediğini bildirmişlerdir.

Bacillus türleri içerisinde antagonistik özelliği bulunun $B$. subtilis türünün, antibiyotik maddeleri sentezleyebilme özelliğinden ötürü biyolojik çalışmalarda en yoğun üzerinde durulan tür olduğu bilinmektedir (Stein, 2005). B. subtilis türünün farklı moleküler yapıya sahip antimikrobiyal bileşikler üretmeleri, üretilen bileşiklere karşı patojenlerin kolayca dayanıklılık geliştirememesi, olumsuz çevre koşullarına karşı dayanıklı endospor oluşturmaları gibi biyolojik özelliklerinden dolayı biyopestisitlerin üretilmesinde en uygun mikrobiyal türler olduğu bildirilmiştir (Fravel, 2005; Perez-Garcia ve ark., 2011).

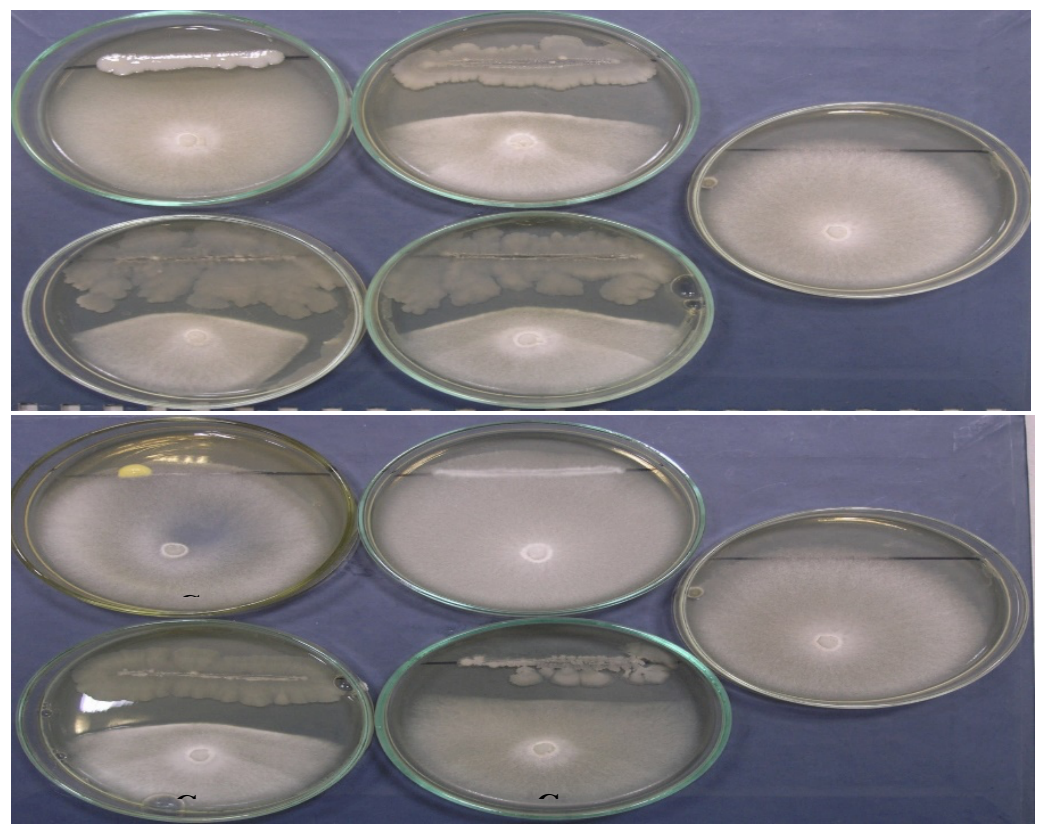

Figure 2. In vitro antagonistic (inhibitory) effect of different antagonistic bacterial isolates on mycelial growth of fungal agent $G$. citri-aurantii. Inefficient isolates (CP6, CP1, CP3) typically failed to inhibit mycelial growth, efficient isolates (CP4, CM8, CT11, CM9,CL10) efficiently inhibited mycelial growth causing inhibition zones

(*) between bacteria and fungal mycelia

Şekil 2. Farklı antagonist izolatların in vitro koşullarda fungal etmen G. citri-aurantii'nin misel gelişimi üzerine olan antagonizm (engelleme) etkinliği. Misel gelişiminde etkisiz olan izolatların (CP6, CP1, CP3) misel gelişimini durduramazken, etkili izolatların (CP4, CM8, CT11, CM9,CL10) misel gelişimini bakteri ile temasa geçmeden etkili bir şekilde durdurarak engelleme zonlarının (*) oluşumuna neden olmuştur 


\section{5. Ön inkübasyon süresi ile antagonistik etkinlik arasındaki ilişkinin belirlenmesi}

Etkili bulunan endofitlerden B. subtilis CP4 izolatının ön inkübasyon süresine bağlı olarak etkinliğinde artış olduğu, en yüksek etkinliğin bakteri inokulasyonundan 2 gün sonra yapılan uygulama petrilerinde gözlenmiştir (Tablo 2). Ön inkübasyon süresine bağlı olarak antagonist bakteri izolatları tarafindan besi yerlerinde üretilen antimikrobiyal maddelerin türü ve miktarının önemli düzeyde etkisi olduğu yapılan diğer çalışmalarda da bildirilmiştir (Yoshida ve ark., 2001).

Tablo 2. Endofit antagonist B. subtilis CP4 izolatının in vitro koşullarda ön inkübasyon süresine bağlı olarak misel gelişimini engelleme (\%) potansiyeli

Table 2. Inhibitory potential (\%) of endophytic antagonist B. subtilis CP4 isolate for mycelial growth inhibition based on pre-incubation time.

\begin{tabular}{ccc}
\hline Ön inkübasyon süresi (saat) & Fungus hif gelişimi $(\mathbf{m m})^{\mathbf{b}}$ & $\begin{array}{c}\text { Misel gelişiminin } \\
\text { engelleme oranı (\%) }\end{array}$ \\
\hline 1 & $19.3^{\mathrm{b}}$ & 55.7 \\
24 & $14.7^{\mathrm{b}}$ & 66.4 \\
48 & $11.7^{\mathrm{a}}$ & 78.6 \\
\hline
\end{tabular}

a Bakteri izolatları PDA üzerine patojen inokulasyonundan 1, 24 ve 48 saat önce çizilmiştir. Engelleme bölgeleri ölçülerek kontrol petrilerdeki gelişmeye göre kıyaslanmış ve engelleme oranları (\%) hesaplanmıştır.

${ }^{\mathbf{b}}$ Elde edilen değerler 5 farklı petri kabında ölçümlerin ortalaması olup, deneme farklı zamanlarda 2 kez tekrar edilmiştir. Sütun içerinde yer alan ortalama değerlerin yanındaki farklı harfler izolatlar arasındaki farkın istatistiksel olarak önemli olduğunu göstermektedir (Duncan Çoklu Karşılaştırma Testi, $P<0.05$ ).

\subsection{Endofit bakteri izolatlarının fungus hiflerinde neden oldukları morfolojik değişikliklerin belirlenmesi}

Antagonist izolatlarının bulunduğu ikili kültür testlerinde etkili bakterilerin fungusların hifleri üzerinde sebep olduğu morfolojik değişiklikler Nomarski DIC ekipmanlı 1şık mikroskobu altında gözlenmiştir. İkili kültür petrilerindeki engellenme bölgelerine yakın yerlerde yapılan ışık mikroskobu gözlemlerinde Bacillus spp. ait bakteri izolatların petri yüzeyinde misel gelişiminin durdurulduğu noktalardaki hiflerin boyunda kısalmalara, şişkinliklere ve boğumlanmalara (Şekil 3D), hifler üzerinde kıvrılma, nekrotikleşme, pıhtılaşma ve sitoplazmik içeriğin (protoplazma) dışarı boşalması (Şekil 3EF) şeklinde morfolojik değişikliklere neden olmuştur. Bu tür değişikliklerin izlendiği petrilerin engelleme bölgelerine akın yerdeki morfolojik bozulmaların gözlendiği miseller taze PDA besiyeri içeren petrilere aktarıldıklarında gelişmemiş olmaları, bu tür misellerin canlılığını tamamen kaybetmiş olduklarını göstermiştir. Daha önce yapılan biyolojik mücadele çalışmalarında farklı Bacillus spp. ait antagonist izolatların Fusarium, Rhizoctonia, Phytophthora, Sclerotinia spp gibi toprak kökenli hastalık etmeni fungal türlerin miselleri üzerinde çalışmalarımızda tespit edilen sitoplazmik vakolleşme, pıhtılaşma, sitoplazmik içeriğin dışarıya boşalması gibi benzer morfolojik değişikliklere neden olduğu gerek 1şık gerekse elektron mikroskobu çalışmalarında da bildirilmiştir (Soylu ve ark., 2005; Akgül ve Mirik, 2008; Pane ve Zaccardelli, 2015; Han ve ark., 2016). Amer ve ark. (1997) antagonist Bacillus bakteri izolatın, domateslerde sorun olan fungal etmenlerden Pythium ultimum ve Fusarium oxysporum hiflerine tutunduktan sonra üretmiş oldukları enzimler sonucunda hiflerde erimelere ve morfolojik bozulmalara neden olduğunu bildirmişlerdir. Bir diğer çalışma ile Gupta ve ark. (2001) patates kök bölgesinden izole ettikleri kök bakterisi Pseudomonas GRC2 izolatının Macrophomina phaseolina ve Sclerotinia sclerotiorum hiflerinde aşırı derecede yapısal bozulmalar, deformasyonlar, pıhtılaşma ve erimeler şeklinde belirtilere neden olduğunu, bu sebeplede fungal etmenlerin besiyerinde sklerot oluşturamadıklarını bildirmişlerdir. Önceden yapılmış birçok çalışmada fungal etmenlere karşı gösterilen antagonistik etki ve hifsel bozulmaların, bakterilerin üretmiş oldukları antifungal sekonder bileşiklerden (uçucu hidrojen siyanid, hücre duvarını yıkan chitinase, protease gibi litik enzimlerden) kaynaklandığını belirlemişlerdir (Veliz ve ark., 2017). 

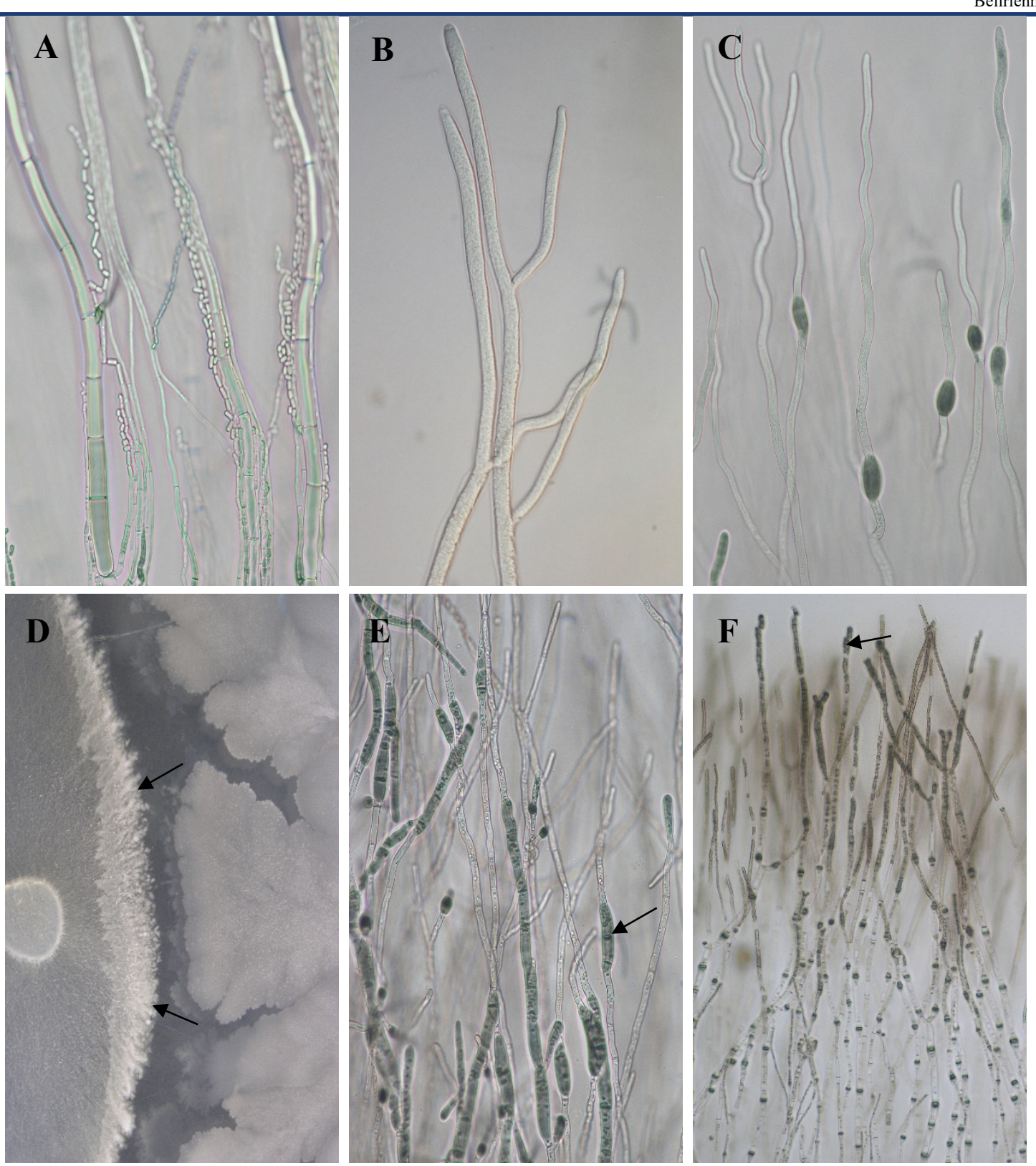

Figure 3. Morphological changes caused by antagonist B. subtilis CM8 isolate on hyphae of G. citri-aurantii under light microscope. (A-C) Typical appearance of healthy hyphae; (D-F) Typical morphological changes observed on hyphae near inhibition zone. (D) Typical aggregates and knotting formation (arrow) on hyphae near inhibition zones. (E-F) Typical morphological abnormalities (arrows) observed on fungal hyphae near inhibition zones such as swellings, vacuolations, coagulations, and necrotic appearance at the tips of the fungal hyphae

Şekil 3. Antagonist B. subtilis CM8 izolatının in vitro koşullarda G. citri-aurantii hifleri üzerinde sebep olduğu morfolojik değişikliklerin ışılk mikroskobu altındaki görünüş̧leri. $(A-C)$ Kontrol petrilerdeki sağllklı hif görünümlerini; (D-F) Antagonist bakteriye en yakın noktalarda morfolojik değiş̧iklerin görüldü̆g̈ü petrilerdeki hifler. (D) Fungus hifinin bakteriye yakın engelleme bölgesine ulaştı̆̆ yerdeki uç noktasındaki kümeleşme ve boğumlaşma şeklindeki görünüm (ok). (E-F) Antagonist bakterin engelleme bölgesine yakın olan fungus hifleri ve sitoplazmalarında şişkinlikler, pıhtılaşma, vakuolleşme ve uçlarında kahverengileşme şeklinde görülen nekrozim oluşumlart şeklindeki morfolojik anormallikler (ok) 
Barka ve ark. (2002), PGPR özellikteki Pseudomonas sp. PsJN izolatının bitki büyümesini teşvik etmesinin yanı sıra asmada sorun Botrytis cinerea gelişimini in vitro ikili kültür ortamında etkili bir şekilde baskılayabildiğini, bakteri izolatının fungal hiflere temas ettiği noktalarda yapılan mikroskobik çalışmalarda antagonistik etkinin engelleme bölgesindeki fungus hiflerinde aşırı düzeyde hifsel bozulmalar, sitoplazmik dejenerasyon, pıhtılaşma ve sonuçta sitoplazmik içeriğin hif dışına boşalma şeklinde belirtilerden kaynaklandığını bildirmişlerdir. Chaurasia ve ark (2005) çay bitkisinin kök bölgesinden izole ettikleri antagonist Bacillus subtilis izolatının 4 tanesi bitki patojeni, 2 tanesi klinik patojen olmak üzere 6 farklı fungal etmenin misel ve konidial yapılarında in vitro morfolojik anormalliklere sebep olduğunu, bu değişikliklerin bakteri tarafından üretilen difüze olabilen ve uçucu yapıdaki antifungal bileşik(ler)den kaynaklandığını, bileşiklerin etkinliğinin besi yerinde misele yakın noktalarda difüze olmak suretiyle fungus hiflerinin sitoplazmalarında çalışmalarımızda gözlenen belirtilere benzer koagülasyon (pıhtılaşma), vakuolleşme ve hücre duvarlarında erime şeklinde etkili olduğunu bildirmişlerdir.

\subsection{Endofit bakteri izolatlarının in vivo koşullarda hastalık gelişimi üzerine biyoetkinliklerinin belirlenmesi}

Endofit bakteri izolatlarının in vivo koşullarında hastalık çıkışı üzerine olan etkinliğinin belirlendiği çalışmalarda, endofit bakteri uygulaması yapılan meyvelerde [patojensiz (negatif kontrol) ve patojenle bulaşık (pozitif kontrol)] hastalık çıkışı ve gelişimini önleme potansiyelleri belirlenmiştir. Hastalık etmeninin inokule edildiği noktalardaki hastalık gelişimi yumuşama alanlarının oluşup oluşmadığı ve çapları ölçülmek sureti ile yapılmıştır (Şekil 4). Sadece hastalık etmeninin verildiği kontrol uygulamalarındaki mandarin meyveleri üzerinde inokulasyondan 3 gün sonra yumuşama şeklinde belirtiler gözlenmiş olup, inokulasyonun 5. gününde meyveler tamamen çürümüş, inokulasyon noktasında fungal hif gelişimleri gözlenmiştir (Şekil 4). Hastalık değerlendirmeleri inokulasyondan 4 gün sonra yapılmıştır (Tablo 3). Elde edilen sonuçlar izolatarın in vitro koşullarda fungal hif gelişimini engelledikleri sonuçlara paralel bir etkinlik göstermiştir.

Tablo 3. Antagonist endofit bakteri izolatının in vivo koşullarda fungal hastalık etmeni G. citri-aurantii tarafindan neden olunan çürümeleri engelleme (\%) potansiyeli ${ }^{a}$

Table 3. Inhibition potential (\%) of antagonist endophytic bacterial isolates on sour rotting caused by G. citriaurantii in vivo conditions ${ }^{a}$

\begin{tabular}{lcc}
\hline Tür ismi & $\begin{array}{c}\text { Yumuşak } \\
\text { çürüklük (mm) }\end{array}$ & $\begin{array}{c}\text { Çürüklük oluşumunu } \\
\text { engelleme oranı (\%) }\end{array}$ \\
\hline Serratia marcescens CT6 & $25.0^{\mathrm{e}}$ & 47.9 \\
Bacillus subtilis CP4 & $15.0^{\mathrm{b}-\mathrm{d}}$ & 68.8 \\
Bacillus subtilis CM8 & $8.0^{\mathrm{b}}$ & 83.3 \\
Bacillus amyloliquefaciens CT11 & $17.0^{\mathrm{cd}}$ & 64.6 \\
Acinetobacter lwoffii CP1 & $45.0^{\mathrm{f}}$ & 6.3 \\
Stenotrophomonas maltophilia CP3 & $48.0^{\mathrm{f}}$ & 0.0 \\
Bacillus amyloliquefaciens CM9 & $13.0^{\mathrm{bc}}$ & 72.9 \\
Bacillus subtilis CL10 & $22.0^{\mathrm{de}}$ & 54.2 \\
Bacillus subtilis CL12 & $13.0^{\mathrm{bc}}$ & 72.9 \\
Bacillus subtilis CL15 & $15.0^{\mathrm{b}-\mathrm{d}}$ & 68.8 \\
Su+G. citri-aurantii (pozitif kontrol) & $48.0^{\mathrm{f}}$ & 0.0 \\
Su+Bacillus subtilis CM8 (negatif kontrol) & $0.0^{\mathrm{a}}$ & 100.0 \\
\hline
\end{tabular}

a Bakteri izolatları meyve üzerine patojen inokulasyonundan 10 dak sonra püskürtülmüş, inokulasyondan 4 gün sonra inokulasyon noktaları incelenerek çürüme (yumuşama) gösteren meyve sayıları kontrol uygulamasındaki meyve sayılarına kıyaslanmış ve hastalık çıkış (engelleme) oranları (\%) hesaplanmıştır.

b Elde edilen değerler 3 farklı plastik kapda (her kapta 5 meyve) tespit edilen hastalıklı meyve sayısının ortalaması olup, deneme farklı zamanlarda $2 \mathrm{kez}$ tekrar edilmiştir. Sütun içerinde yer alan ortalama değerlerin yanındaki farklı harfler izolatlar arasındaki farkın istatistiksel olarak önemli olduğunu göstermektedir (Duncan Çoklu Karşılaştırma Testi, $P<0.05$ ).

In vivo çalışmalarda bakteri türler arasında Bacillus spp. fungal etmeni ile infekte edilmiş meyvelerde hastalık oluşumunu (çıkışı) \%54.2-83.3 gibi oldukça yüksek oranda engellediği belirlenmiştir (Tablo 3). İzolatlar arasında en yüksek antagonistik etki, in vitro çalışmalarda fungus misel gelişimini en fazla engelleyen izolatlardan $B$. subtilis CM8 nolu izolatın kullanıldığı meyvelerde \%83.3 oranında tespit edilmiştir (Tablo 3). Test edilen izolatlar arasından, Stenotrophomonas maltophilia CP3 ile Acinetobacter lwoffii CP1 izolatları uygulandikları meyvelerde hastalık çıkışını engellemede başarılı olamamış, sonuçta sadece steril su+patojenin verildiği kontrol uygulaması 
Soylu \& Kara \& Soylu \& Uysal \& Kurt Geotrichum citri-aurantii'nin Sebep Olduğu Turunçgil Ekși Ç̋̈rüklük Hastalığının Biyolojik Mücadelesinde Endofit Bakterilerin Biyokontrol Potansiyellerinin Belirlenmesi

ile aynı istatistiksel grupta yer almıştır. Bacillus türleri dışında bir diğer antagonist tür olan Serratia marcescens CT6 izolatı hastalık çıkışında \%47.9 oranda engellemiş olup, B. subtilis CL10 nolu izolat hariç, diğer Bacillus spp. izolatlarla istatistiksel olarak farklı bir grupta yer almıştır (Tablo 3).

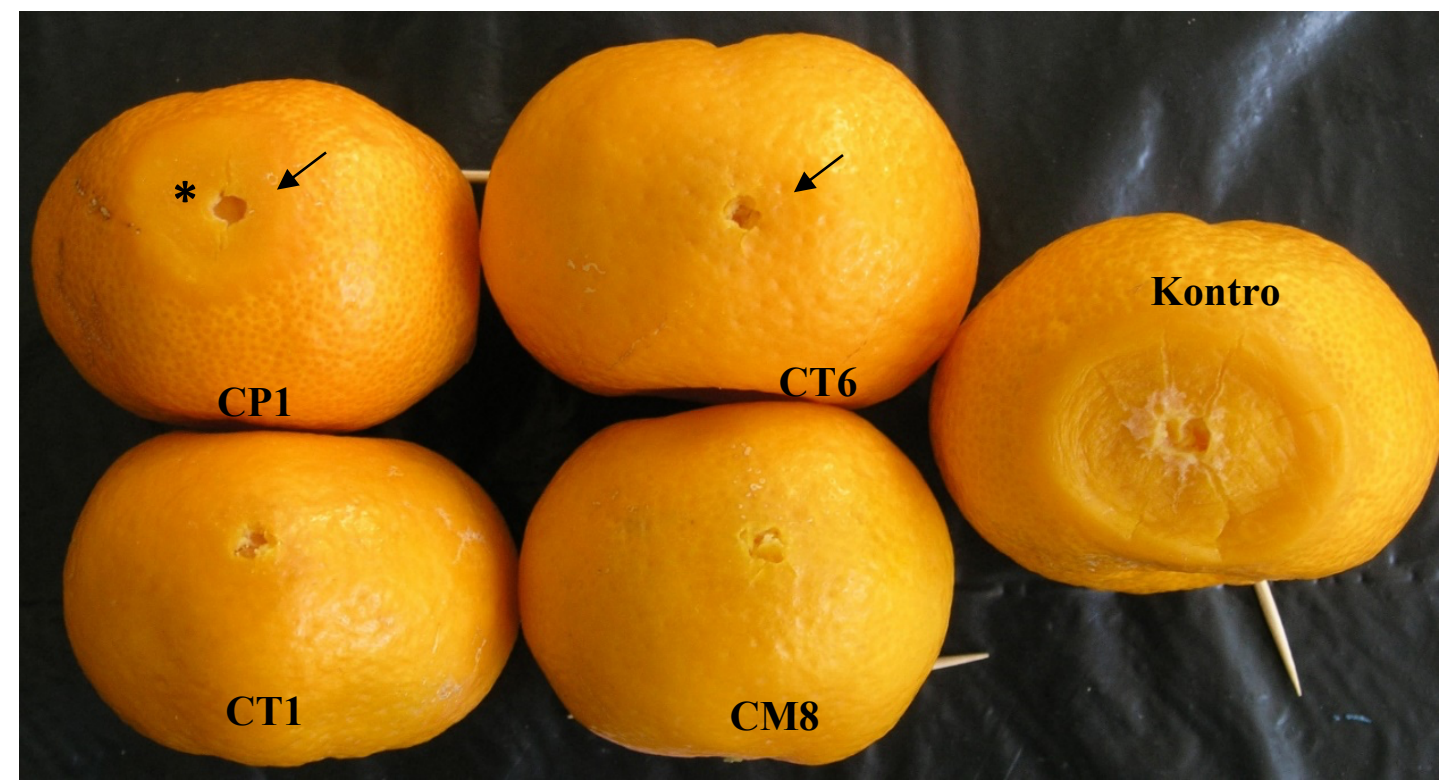

Figure 4. Antagonistic (inhibitory) effects of bacterial isolates on disease development caused by fungal agent G. citri-aurantii in vivo conditions. Disease developments (*) or suppression of disease symptoms (arrow) at the inoculation sites

Şekil 4. Antagonist izolatların in vivo koşullarda fungal etmen G. citri-aurantii tarafindan neden olunan hastalı gelişimi üzerine olan antagonizm (engelleme) etkinliği. Uygulama yapılmış noktalarda hastalığın gelişimi (*) veya farklı düzeylerde engellenmesi (ok)

Turunçgillerde sorun fungal hastalıklara karşı yapılan biyolojik mücadele araştırmalarının çoğunluğu sadece Penicillium digitatum'a odaklanmış olup, Penicillium italicum ve G. citri-aurantii gibi diğer önemli turunçgil depo patojenlerine karşı yapılmış oldukça az çalışma bulunmaktadır. Soto ve ark., (2018) tarafindan yapılan çalışmada, Bacillus amyloliquefaciens, Bacillus subtilis, Paenibacillus polymyxa, Pantoea aglomerans, Pseudomonas syringae, Candida membranifaciens, Candida utilis, Cryptococcus laurentii, Debaryomyces hansenii, Kloeckera apiculata, Metschnikowia spp., Pichia guilliermondii, Pichia membranifaciens, Rhodosporidium paludigenum, Saccharomyces cerevisiae, Aureobasidium pullulans, Nodulisporium spp., ve Trichoderma spp gibi antagonistik mikroorganizmaların limon meyvelerinde sorun olan Geotrichum citri-aurantii, Penicillium digitatum, Penicillium italicum ve Phyllosticta citricarpa gibi hasat sonu fungal hastalıkların mücadelesinde oldukça etkili olduğu bildirilmiştir. Hong ve ark. (2014) Bacillus amyloliquefaciens HF-01, sodium bicarbonate (SBC) ve sıcak su uygulamaların (HW) mandarin meyvelerinde Penicillium digitatum, P. italicum ve Geotrichum citri-aurantii tarafından neden olunan küf ve ekşi çürüklük hastalıklarına karşı mücadele imkânlarını araştırdıkları çalışmalarında B. amyloliquefaciens $+\% 2 \mathrm{SBC}$ ve/veya $45^{\circ} \mathrm{C} \mathrm{HW}$ ( 2 dak.) şeklinde yapılan uygulamaların hastalık çıkışını (çürümeyi) kontrol uygulamasına kıyasla \%80 gibi oldukça yüksek oranda engellediğini, uygulamanın etkinliğinin kimyasal uygulama kadar etkili olduğunu bildirmişlerdir. Yakın zamanda yapılan çalışmada, farklı kompost materyallerinden izole edilmiş Bacillus türlerine ait antagonist bakteri izolatlarının tekli ve bor ürünleri ile kombinasyon halinde hazırlanan karışımların laboratuvar (in vitro) ve yarı ticari koşullarındaki (yarı in vivo) antifungal etkinliği Geotrichum citri-aurantii'ye karşı belirlenmiştir (Gedik, 2019). Yapılan in vitro çalışmalarında Bacillus spp.'ye ait 19 antagonist izolat arasında fungal etmenin misel gelişimini engelleyen en etkili antagonist izolatlar \% 66.95 ve \% 66.10 engelleme oranı ile Bacillus cereus (G1B:3:6) ve B. pumilus (G4B:0:4) izolatlar olmuştur. Test edilen antagonist bakteri izolatlardan Bacillus subtilis (K3B:4:8:1), B. subtilis (G3B:3:5), Bacillus amyloliquefaciens (K5B:0:5:1), Bacillus pumilus (G4B:0:4) ve Bacillus thuringiensis (G2B:0:4) borik asit+boraks (0.5-1.0 g/L) uygulamaları patojen gelişimini engellemede etkisiz olarak değerlendirilmiştir. G. citri-aurantii'nin 
misel gelişimini yüksek oranda engelleyen aynı zamanda borik asit+boraks karışımında canlılığını koruyabilen antagonist bakteri izolatların tekli ve borik asit+boraks ile karışımlarının hastalık çıkışının engellenmesi üzerine olan koruyucu ve tedavi edici etkinlikleri yarı in vivo koşullarda araştırılmıştır. Söz konusu uygulamaların koruyucu etkinliği, tedavi edici etkinliğine kıyasla daha yüksek düzeyde gerçekleşmiştir. Bacillus subtilis G3B:3:5, Bacillus pumilus G4B:0:4, Bacillus subtilis K3B:4:8:1, Bacillus amyloliquefaciens K5B:0:5:1 teksel veya borik asit+boraks karışımı $(0.5 \mathrm{~g}+1.0 \mathrm{~g} / \mathrm{L})$ ile birlikte koruyucu uygulaması in vivo hastalık çıkışını \%81.9-89.7 düzeyinde engellemiştir. Uygulamaların tedavi edici etkinliğinin araştırıldığı çalışmada, uygulamaların hastalık çıkışının engellenmesi üzerinde olan etkinliklerinin \% 40.3-54.9 düzeylerinde olduğu görülmüş̧ür.

\section{Sonuç}

Sonuç olarak, sağlıklı bitkilerin iç dokularından izole edilen endofit antagonist mikroorganizmalar laboratuvar koşullarında geliştirilen mikroorganizmalara oranla gerek ortama daha hızlı adaptasyon sağlaması gerekse minimum düzeyde yetişme şartlarına ihtiyaç duyması nedeniyle biyolojik mücadeledeki başarı şanslarının daha yüksek olduğu bilinen bir gerçektir. Çevre dostu, biyolojik kökenli bu mikroorganizmaların kullanılmasıyla üretim alanlarında pestisit uygulamalarının büyük oranda azaltılması pestisitlerin çevreye ve insan sağlığına olan olumsuz etkilerinin ortadan kalkmasına katkıda bulunacaktır. Bu tür faydalı mikroorganizmaların kullanılmasının pratiğe aktarılması ile ülkemiz ve bölgemiz açısından önemli ürünlerden olan meyve ve sebzelerin organik tarıma önem veren gelişmiş ülkelere daha fazla ihraç etme firsatı yakalanabilecektir. Bu çalışmadan fungal etmene karşı in vitro ve yarı in vivo teslerde etkinlik gösteren farklı Bacillus spp. ait izolatların ticari biyolojik preparatlarının yapılarak gerek turuçgillerde gerekse ülkemiz ekonomisine katkı sağlayan diğer meyve ve sebzelerde sorun olan fungal ve bakteriyel hastalıklara karşı etkinliklerinin belirlenmesi gelecekte yapılması gereken önemli çalışmalar olarak değerlendirilmiştir. 
Soylu \& Kara \& Soylu \& Uysal \& Kurt Geotrichum citri-aurantii’nin Sebep Olduğu Turunçgil Ekși Çürüklük Hastalığının Biyolojik Mücadelesinde Endofit Bakterilerin Biyokontrol Potansiyellerinin Belirlenmesi

\section{Kaynakça}

Akgül, D. S., Mirik, M. (2008). Biocontrol of Phytophthora capsici on pepper plants by Bacillus megatarium strains. Journal of Plant Pathology, 90 (1): 29-34.

Aktan, C., Soylu, S. (2020). Diyarbakır ilinde yetişen badem ağaçlarından endofit ve epifit bakteri türlerinin izolasyonu ve bitki gelişimini teşvik eden mekanizmalarının karakterizasyonu. KSÜ Tarım ve Doğa Dergisi 23 (3): 641-654.

Amer, G.A., Aggarwal, R., Singh, D.V., Srivastava, K. D. (1997). Interaction of Bacillus thuringiensis with Pythium ultimum and Fusarium oxysporum f. sp. lycopersici: Possible role in biological control. Current Sciences 3: 284-286.

Anonim (2020a). Yaş Meyve Sebze Sektörü Türkiye Geneli Değerlendirme Raporu.

https://www.akib.org.tr/files/documents/2020/Rapor/Ekim $\% 202020 \% 20$ YMS $\% 20 \%$ C4\%B0hracat $\% 20$ De $\%$ C4\%9Ferlendirme $\% 20$ Rapo ru.pdf, 38 sayfa.

Anonim (2020b). TUİK Bitkisel Üretim İstatistikleri, https://biruni.tuik.gov.tr/medas/?kn=92\&locale=tr, (Erişim tarihi: 20.04.2021).

Anonymous (2019). Food and Agriculture Organization of the United Nations (FAO), http://www.fao.org/site, (Erişim tarihi: 20.04.2021).

Barka, E.A., Gognies, S., Nowak, J., Audran, J.C., Belarbi, A. (2002). Inhibitory effect of endophyte bacteria on Botrytis cinerea and its influence to promote the grapevine growth. Biological Control 24: 135-142.

Bazioli, J.M., Belinato, J.R., Costa, J.H., Akiyama, D.Y., Pontes, J.G.D., Kupper, K.C., Augusto, F., de Carvalho, J.E., Fill, T.P. (2019). Biological control of citrus postharvest phytopathogens. Toxins 11 (8): 460.

Bora, P, Bora, L.C. (2020). Disease management in horticulture crops through microbial interventions: An overview. Indian Journal Of Agricultural Sciences 90 (8): 1389-1396.

Bozkurt, İ.A., Soylu, S. (2019). Elma kök uru hastalığı etmeni Rhizobium radiobacter'e karşı epifit ve endofit bakteri izolatlarının antagonistik potansiyellerinin belirlenmesi. Tekirdağ Ziraat Fakültesi Dergisi 16: 348-361.

Carmona-Hernandez, S., Reyes-Perez, J.J., Chiquito-Contreras, R.G., Rincon-Enriquez, G., Cerdan-Cabrera, C.R., Hernandez-Montiel, L.G. (2019). Biocontrol of postharvest fruit fungal diseases by bacterial antagonists: a review. Agronomy-Basel 9 (3): 121.

Chalupová, J., Raus, M., Sedlarova, M, Sebela, M. (2014). Identification of fungal microorganisms by MALDI-TOF mass spectrometry. Biotechnology Advances 32(1):230-41.

Chaurasia, B., Pandey, A., Palni, L.M.S., Trivedi, P., Kumar, B., Colvin, N. (2005). Diffusible and volatile compounds produced by an antagonistic Bacillus subtilis strain cause structural deformations in pathogenic fungi in vitro. Microbiological Research 160: 75-81.

Duman, K., Soylu, S. (2019). Characterization of plant growth-promoting traits and antagonistic potentials of endophytic bacteria from bean plants against Pseudomonas syringae pv. phaseolicola. Bitki Koruma Bülteni 59:59-69.

Eckert J.W., Eaks I.L. (1989). Postharvest disorders and diseases of citrus fruits. In: Reuter W., Calavan E.C. \& Carman G.E. (Eds), The citrus industry, vol. 5. Univ. Calif. Press, Berkeley, USA, pp. 179-260.

Eljounaidi, K., Lee, S.K., Bae, H. (2016). Bacterial endophytes as potential biocontrol agents of vascular wilt diseases - Review and future prospects. Biological Control 103: 62-68.

Feng, W., Chen, J., Zheng, X., Liu, Q. (2011). Thyme oil to control Alternaria alternate in vitro and in vivo as fumigant and contact treatments. Food Control 22: 78-81.

Fravel, D.R. (2005). Commercialization and implementation of biocontrol. Annual Review of Phytopathology 43: 337-359.

Gedik, M. (2019). Turunçgilde derim sonrası ekşi çürüklük hastalığl etmeni Geotrichum citri-aurantii'ye karşı antagonist bakteriler ve bor ürünlerinin antifungal etkileri. (Yüksek Lisans Tezi) Hatay Mustafa Kemal Üniversitesi, Bitki Koruma A.B.D., Hatay.

Ghazanfar, M.U., Hussain, M., Hamid, M.I., Ansari, S.U. (2016). Utilization of biological control agents for the management of postharvest pathogens of tomato. Pakistan Journal Of Botany 48 (5): 2093-2100.

Gupta, C.P., Dubey, R.C., Kang, S.C., Maheshwari, D.K. (2001). Antibiosis-mediated necrotrophic effect of Pseudomonas GRC2 against two fungal plant pathogens. Current Science 81: 91-94.

Han, T., You, C., Zhang, L., Feng, C., Zhang, C., Wang, J., Kong, F. (2016). Biocontrol potential of antagonist Bacillus subtilis Tpb55 against tobacco black shank. Biocontrol 61 (2): 195-205.

Hao, W., Zhong, G., Hu, M., Luo, J., Weng, Q., Rizwan-ul-Haq, M. (2010). Control of citrus gren and blue mold and sour rot by tea saponin combined with imazalil and prochloraz. Postharvest Biology and Technology 56: 39-43.

Hong, P., Hao, W., Luo, J., Chen, S., Hu, M., Zhong, G. (2014). Combination of hot water, Bacillus amyloliquefaciens HF-01 and sodium bicarbonate treatments to control postharvest decay of mandarin fruit. Postharvest Biology and Technology 88: 96-102.

Horuz, S. (2009). Turunçgillerde ekşi çürüklük etmeni Geotrichum citri-aurantii (Ferraris) E. E. Butler'e bazı fungisitlerin etkililikleri üzerinde araştırmalar. (Yüksek Lisans Tezi) Ege Üniversitesi, Bitki Koruma A.B.D., İzmir. 
Horuz, S., Kinay, P. (2010). The effects of some new postharvest fungicides and combination of hot water with sodium bicarbonate against Geotrichum citri-aurantii on citrus. Acta Horticulturae 877: 1551-1557.

Horuz, S., Karut, Ş. T., Aysan, Y. (2019). Domates bakteriyel kanser ve solgunluk hastalı̆̆1 etmeni Clavibacter michiganensis subsp. michiganensis'in tohumda aranması ve tohum uygulamalarının patojen gelişimine etkisinin belirlenmesi. Tekirdağ Ziraat Fakültesi Dergisi 16: $284-296$

Kara, M., Soylu, E. M. (2020). Assessment of glucosinolate-derived isothiocyanates as potential natural antifungal compounds against citrus sour rot disease agent Geotrichum citri-aurantii. Journal of Phytopathology 168: 279-289.

Kara, M., Soylu, S., Kurt, Ş., Soylu, E. M., Uysal, A. (2020). Determination of antagonistic traits of bacterial isolates obtained from apricot against green fruit rot disease agent Sclerotinia sclerotiorum. Acta Horticulturae 1290:135-142.

Kong, Q.J., Liang, Z., Xiong, J., Li, H. B., Ren, X. Y. (2016). Overexpression of the bivalent antibacterial peptide genes in Pichia pastoris delays sour rot in citrus fruit and induces Geotrichum citri-aurantii cell apoptosis. Food Biotechnology 30 (2): $79-97$.

Lelliot, R.A., Stead, D.E. (1987). Methods for the diagnosis of bacterial diseases of plants. (T.F. Preece, Editör). In: Methods in plant pathology. Vol 2, Blackwell Scientific Publications. pp. 176-177, Oxford.

Liu, X., Wang, L.P, Li, Y.C., Li, H.Y., Yu, T., Zheng, X.D. (2009). Antifungal activity of thyme oil against Geotrichum citri-aurantii in vitro and in vivo. Journal of Applied Microbiology 107: 1450-1456.

Liu, X., Fang, W., Liu, L., Yu, T., Lou, B., Zheng, X. (2010). Biological control of postharvest sour rot of citrus by two antagonistic yeasts. Letters in Applied Microbiology 51: 30-35.

Liu, Y., Yao, S., Deng, L., Ming, J., Zeng, K. (2019). Different mechanisms of action of isolated epiphytic yeasts against Penicillium digitatum and Penicillium italicum on citrus fruit. Postharvest Biology and Technology 152: 100-110.

Maldonado, M.C., Corona, J., Gordillo, M.A., Navarro, A.R. (2009). Isolation and partial characterization of antifungal metabolites produced by Bacillus sp. IBA 33. Current Microbiology 59: 646-650.

McKay, A.H., Förster, H., Adaskaveg, J.E. (2012). Distinguishing Galactomyces citri-aurantii from G. geotrichum and characterizing population structure of the two postharvest sour rot pathogens of fruit crops in California. Phytopathology 102: 528-538.

Mohammadi, P., Tozlu E., Kotan R., Kotan Ş.M. (2017). Potential of some bacteria for biological control of postharvest citrus green mould caused by Penicillium digitatum. Plant Protection Science 53: 134-143.

Pane, C., Zaccardelli, M. (2015). Evaluation of Bacillus strains isolated from solanaceous phylloplane for biocontrol of Alternaria early blight of tomato. Biological Control 84: 11-18.

Perez-Garcia, A., Romero, D., de Vicente, A. (2011). Plant protection and growth stimulation by microorganisms: biotechnological applications of Bacilli in agriculture. Current Opinion in Biotechnology 22 (2): 187-193.

Smilanick, J. L., Mansour, M. F. (2007). Influence of temperature and humidity on survival of Penicillium digitatum and Geotrichum citriaurantii. Plant Disease 91: 990- 996.

Smilanick, J.L., Mansour, M.F., Gabler, F.M., Sorenson, D. (2007). Control of citrus postharvest green mold and sour rot by potassium sorbate combined with heat and fungicides. Postharvest Biology and Technology 47: 226-238.

Soto, F., Tramon, C.P., Aqueveque, P.M., de Bruijn, J. (2018). Antagonist microorganisms that inhibit the development of post-harvest pathogens in lemons (Citrus limon L.). Chilean Journal of Agricultural and Animal Sciences 34 (2): 173-184.

Soylu, S., Soylu, E.M., Kurt, Ş., Ekici, Ö.K. (2005). Antagonistic potentials of rhizosphere-associated bacterial isolates against soil-borne diseases of tomato and pepper caused by Sclerotinia sclerotiorum and Rhizoctonia solani. Pakistan Journal of Biological Sciences 8: 4348 .

Soylu, E.M., Soylu, S., Kara, M., Kurt, Ş. (2020). Sebzelerde sorun olan önemli bitki fungal hastalık etmenlerine karşı vermikomposttan izole edilen mikrobiyomların in vitro antagonistik etkilerinin belirlenmesi. KSU Tarım ve Doğa Dergisi 23: 7-18.

Stein, T. (2005). Bacillus subtilis antibiotics: structures, syntheses and specific functions. Molecular Microbiology 56 (4): $845-857$.

Sturz, A.V., Christie, B.R., Nowak, J. (2000). Bacterial endophytes: potential role in developing sustainable systems of crop production. Critical Reviews in Plant Sciences 19 (1): 1-30.

Sülü, S.M., Bozkurt, İ.A., Soylu, S. (2016). Bitki büyüme düzenleyici ve biyolojik mücadele etmeni olarak bakteriyel endofitler. Mustafa Kemal Üniversitesi Ziraat Fakültesi Dergisi 21 (1): 103-111.

Tan, S., Dong, Y., Liao, H., Huang, J., Song, S., Xu, Y., Shen, Q. (2012). Antagonistic bacterium Bacillus amyloliquefaciens induces resistance and controls the bacterial wilt of tomato. Pest Management Science 69: 1245-1252.

Veliz, E.A., Martinez-Hidalgo, P., Hirsch, A.M. (2017). Chitinase-producing bacteria and their role in biocontrol. Aims Microbiology 3 (3): 689-705.

Wang, Z.S., Sui, Y., Li, J.S., Tian, X.L., Wang, Q. (2020). Biological control of postharvest fungal decays in citrus: a review. Critical Reviews in Food Science and Nutrition: DOI: 10.1080/10408398.2020.1829542.

Yoshida, S., Hiradate, S., Tsukamato, T., Hatakeda, K., Shirata, A. (2001). Antimicrobial activity of culture filtrate Bacillus amyloliquefaciens RC-2 isolated from mulberry leaves. Phytopathology 91: 181-187. 